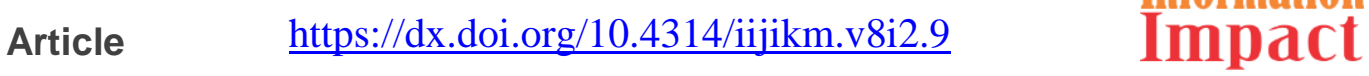

\section{Lecturers' perception of students' information literacy skills versus students' actual information literacy levels}

\section{Dorcas Ejemeh Krubu}

Ambrose Alli University, Nigeria

OgagaOghene Uzezi Idhalama

Ambrose Alli University, Nigeria

Chirstopher Omigie

Ambrose Alli University, Nigeria
Information Impact:

Journal of Information and Knowledge Management 2017, Vol. 8 (2) Pg 99 - 117 ISSN: $2141-4297$ (print) ISSN: 2360 - 994X (e-version) www.informationimpact.org

\begin{abstract}
The main objective of this study is to determine lecturers' perception of students' information literacy skills versus students' actual information literacy levels in a specialised federal university in Nigeria. Mixed qualitative methods of open-ended written interviews with lecturers and analysis of students' written assignment was employed. Twelve open-ended interview protocols were administered to twelve (12) lecturers in various departments in both Colleges of Science and Technology in addition to two librarians who teach the Use of Library and Study Skills Course. In the same vein, individual assignments of the entire 50, third year student of Electrical Electronic Engineering Departments were examined using a rubric prepared by the researchers (founded on the ACRL information literacy standards). The study presented herein is limited to only one department in the university and may not be used for the purpose of generalisation. It was discovered through the findings that students' information literacy level is quite low even in third year while the lecturers present an elevated impression of students' information literacy levels, rating them as excellent/advanced. The study recommends Quality Education in Developing Countries (QEDC)(2008) strategies and QEDC theory of change to serve as point of evaluation and genuine intervention in teaching and learning. The study also recommends regular information literacy education in-service programmes for the teaching staff to aid in enhancing their teaching capacity. The Nigerian Library Association (NLA) should work to develop an information literacy education policy and enforce it in Nigerian universities. The research unravels the status-quo of information literacy in the particular context and explicates the need for the ideal information literacy education. This paper fulfils the need to study the information literacy levels of undergraduates and the possible intervention programs.
\end{abstract}

Keywords: information literacy, skills, lecturers' perception, students' information literacy, information literacy level 


\section{Introduction}

The over abundance of information in a technologically inclined $21^{\text {st }}$ century requires matching skills and ability to efficiently utilize information. This set of skills referred to as information literacy is a graduate attribute. The tertiary institution is a platform for learning and acquiring these much needed skills. Understanding the contextual reality of students' ability to handle information is a necessary step to designing a standard information literacy education which ideally should run through all courses and across all level of study in the tertiary institution. Lecturers who administer the curriculum have the mandate to employ teaching and learning methods that enhance education through critical and democratic pedagogy for social change, which translates to national development. Decisive to the teaching and learning process is the knowledge of students' information literacy levels which can aid in designing the appropriate intervention program to facilitate the desired education for "change". To this effect, the study attempts to unravel lecturers' perception of students' information literacy skills and their actual information literacy level, using the case of a specialised Nigerian university.

Information literacy is the ability to recognize an information need, efficiently access information sources and evaluate information in a bid to closing the gap in knowledge. This ability is a set of skills that is needed in the $21^{\text {st }}$ century work place, more so as "the uncertain quality and expanding quantity of information pose large challenges for society" (ACRL, 2000:4). These set of skills called information literacy skills are a must-have requirement for undergraduates in all fields of endeavour. Information literacy skill is dependent on the individual's cognitive abilities (Kuhlthau, 2004, 2008; Krubu, 2013, 2015), language competence (Bellardo, 1985: 237) and technological literacy (Burnett and Jaeger, 2011:167168). Information literacy skills are a key part of the graduate attributes and skills set required by the work place in Nigeria (Krubu, 2015). Johnson and Webber (2003) is of the view that information literacy is the adoption of appropriate information behaviour obtained through whatever channel or medium, information well fitted to information needs, together with a critical awareness of the importance of wise and ethical use of information in the society.

According to Ojedokun (2007) information literacy is common to all disciplines and to all levels of education. Successful information literacy programme is aimed at making sure that an information gap is recognized, information searched for, evaluated and put to use appropriately and legally. Information literacy is knowing what, where and how to use information well. The proliferation of information in a world driven by technology requires a complementary ability to use information meaningfully and creatively; this is what (Kuhlthau, 2012:18) describes as the hard part of information (technology) use. Armstrong (2005) defined information literacy as the acquired skills to know when and why one needs information, where to find it and know how to evaluate, use and communicate it in an ethical manner. 
The skills encapsulated in information literacy are both expedient on the part of the lecturers and students alike; if students are therefore well grounded in the skills, worthwhile and smooth academic journey is guaranteed. To this end, the researchers attempt to match the lecturers' perception of students' information literacy skills with their actual information literacy level.

The findings of this research will explicate the aspect of teaching and learning that requires review and intervention in Nigerian universities in the same context.

The Association of College Research Libraries (ACRL) (2012) has spelt out five information literacy standards, each with its performance indicators and outcomes for assessing the progress of tertiary students studying science and engineering or technology at all levels of higher education towards information literacy. The aim of these standards is to entrench information literacy across all curricula in all tertiary educational programmes in collaboration with the efforts of faculty, librarians and administrators.

The five standards set by the ACRL (2005:5-6) to describe someone who is information literate are as follows:

An information literate individual is able to:

- Determine the nature and extent of information needed.

- Access and gather the needed information effectively and efficiently.

- Evaluate and critique information and its sources.

- Understand the economic, legal, and social issues surrounding the use of information, and access and use information ethically and legally, either as an individual or a member of a group.

- Understand that information literacy is an on-going process and uses a variety of methods and emerging technologies for keeping abreast of trends in the field.

These standards are captured in Kuhlthau's topical definition of information literacy; that is the ability to locate, evaluate and use information wisely for learning, thinking and creating (2012: 6).

In this study, the ACRL information literacy standards were used as theoretical framework to explore the students' information literacy level. 


\section{Literature review}

Information literacy is a crucial skill in the technologically infused $21^{\text {st }}$ century; it is recognized in the global community and in Nigeria as a driving tool for progress and development in this era of information proliferation. Students are expected to learn and acquire information literacy skills while in the university. However, a number of research works have shown that there are shortcomings in students' information literacy skills.

In her study of sociology and civil engineering faculty, McGuinness (2006) discovered that faculty members' belief that IL is dependent on personal interest and individual motivation, and improves according to the 'law of exposure' as students repeatedly encounter situations requiring their IL skills. Rockson (2004) submit that "just as writing shapes and enhance thoughts, clarifies thinking, and facilitates learning, so does information literacy. Kerins, Madden, and Fulton (2004) in their study of law and engineering students in three Irish Universities found that students who identify the Internet as the best source of information for their project also felt it the worst because of information overload and they are not sure of the reliability of the information on the Internet. This is an indication of the fact that, they have poor information handling skills. One of the attributes of an information literate student is to be able to figure out when information is needed and know the appropriate source to seek information and as well be able to evaluate the information sources available.

Gross and Latham (2008) conducted in-depth interviews with freshmen at Florida State University, USA, in order to explore their perceptions of what information literacy (IL) is, how information literacy is attained, and their self-views of their own information literacy knowledge base and skills set, and to compare these self-views to scores they earn on a standardized test of information literacy. Findings revealed that the undergraduates are not familiar with the term information literacy. Unfortunately, they feel constrained by imposed information seeking as against personal information seeking (Gross \& Latham, 2008: 11-12). Such constraints may be due to poor information search skills. In discussion with these students concerning how they know what they know about how to look for information, most of them see themselves as "self taught."

Also in 2008, the Centre for Information Behaviour and the Evaluation of Research (CIBER), University College London, reported the outcome of the research work lauched by the British Library and Joint Information Systems Committee (JISC). The objective was to identify how the specialist researchers of the future are likely to access and interact with digital resources in five to ten years' time. The study reveals that students have poor information literacy skills: they have poor understanding of their information needs; search engines become the primary 
brand associated with the Internet; and they prefer to use Google.

Similarly, MohdSaad (2008) in his PhD study in Malaysia examined the information literacy and information seeking behaviour of students conducting final year projects at the Faculty of Computer Science and Information Technology, University of Malaysia. The study revealed that even though students know how to go about their final year project, over $80 \%$ of them need assistance in searching from electronic databases (73.6\%), digitised information (67.9\%) and the Internet (59.7\%). The effective use of databases is part of information literacy. Therefore, the skill of getting the right information from the right source is crucial to the success of any research endeavour. Williams (2010:12) summarises the findings of a number of market research studies that have been commissioned by Mimas (www.mimas.ac.uk), which is a nationally designated academic data centre based at The University of Manchester in the United Kingdom. The investigations aimed at understanding how students and researchers interact with, search and conduct research using online resources.Generally, findings revealed low levels of information literacy amongst students at all levels, which validate the outcome of the CIBER Google Generation report of 2008. Therefore, one cannot agree more with Dahlstrom (2012: 5), who contends that technology training and skill development for students is more crucial than new, more, or "better" technology.

Kunakornsakul and Pinit (2012:291-298) investigated the IL skills of undergraduate students in Science and Technology and also identified the needed IL skills for improvement in the field of Science and Technology at King Mongkut's University of Technology, Thonburi in Thailand. Findings reveal that the IL literacy level of the students was low, similar to the outcome of King (2007) in the study of freshmen at the University of the Western Cape, South Africa. Students were found to be weak in five areas of research namely: concept identification; search strategy; documents types; search tools and use of results.

In Nigeria, studies by Baro and Fyneman (2009); Abubakar and Isyaku (2012); Adetimirin (2012); Ukpebor and Emojorho (2012); Krubu (2015) reveal that the information literacy levels of Nigerian undergraduates are inadequate, even though some students have acquired a certain level of information literacy, including technological skills.

Being employable after graduation largely depends on your skills, a graduate who cannot access and utilize information effectively literally stands at a cross road and could be denied employment in the 21st century. Several prominent employers have recognized the value of information literacy (Rockman, 2004). Anthony Comper, the President of the Bank of Montreal, told the 1999 commerce graduating class at the University of Toronto that information literacy is essential to future success. 
"...what we need in the knowledge industries are people who know how to absorbed and analyze and integrate and create and effectively convey information and who know how to use information to bring real value to everything they undertake."

Likewise lecturers' perception varies depending on their knowledge base. Some lecturers are yet to come to terms with the term "information literacy". Adeyemi (2010) stressed that students and researchers need to know what databases and other resources to access, how to extract the relevant data, and how to organize and analyze the data and develop recommendations. Likewise lecturers!

In her research work on the faculty perception of students information literacy skills competencies Dubicki (2013) found out that faculty familiarity with IL concepts was high; faculty are overwhelmingly supportive of IL and are incorporating these skills into learning outcomes for their courses; and there are strong expectations of students' achieving IL skills by graduation, but faculty perceptions are that students fall short of mastering those skills by the end of their programmes.

\section{Methodology}

The section captures the research design and methodology of lecturers' perception of students' information literacy skills versus students' actual information literacy levels, using a specialised Nigerian case study. The choice of the case site is informed by the fact that the specialised university, which is the only one of its kind in Nigeria and Africa, was established in 2007 primarily to meet the demands of the petroleum industry in terms of the production of manpower and expertise. Therefore, due to the strategic position of the specialised university in national development, the researcher deemed it most appropriate as the case site.

The research employed mixed qualitative methods of open-ended written interviews by lecturers and analysis of students' written assignments.

\section{Interviews}

The process of conducting interviews can be described as question and answer sessions. It could be in several forms: face-to-face, electronic, or a written structured to semi structured to unstructured, as the case may demand. An interview is an active process of exchange between two or more people and "leads to a contextually bound and mutually created story" (Fontana \& Frey, 2008: 116-117).

Twelve open-ended interview protocols were administered to 12 lecturers in various departments in both Colleges of Science and Technology, in addition to two librarians who teach the Use of Library and Study Skills course. The open-ended questions focused on the general assessment of 
students and how they seek and use information in attending to their assignments, whether students are directed to use specific information sources, lecturers' familiarity with the concept of information literacy, and the use of the Internet and Web 2.0 tools in the teaching-learning process. However, only the questions on lecturers' perception of students' information literacy levels, that is, how they seek and use information, are of import to this research paper.

\section{Examination of students' assignments}

The individual assignments of the entire 50, third year students of Electrical Electronics Engineering Departments were examined. This was done in order to gather information that would aid the researchers in ascertaining the actual level of students' information handling skills. The assignment scripts were evaluated using a rubric prepared by the researchers. The rubric is founded on the ACRL information literacy standards (ACRL, 2012). Standards two to five were used as a lens to evaluate students' information literacy skills in their assignments. The rubric was piloted with three assignments after which it was further reviewed before use.

\section{Findings and discussions}

This section reveals findings from the interviews with lecturers on their perception of students' information literacy skills and students' actual information literacy skills, as revealed by the qualitative analysis of assignment.

\section{Lecturers' perceptions of students' information literacy skills}

The proliferation of information in a world driven by technology requires a complementary ability to use information meaningfully and creatively; this is what Kuhlthau describes as the hard part of information (technology) use (Kuhlthau, 2012:18). This ability is a set of skills called information literacy. The five standards set by the ACRL (2005:5-6) to describe someone who is information literate are as follows:

An information literate individual is able to:

- Determine the nature and extent of information needed.

- Access and gather the needed information effectively and efficiently.

- Evaluate and critique information and its sources.

- Understand the economic, legal, and social issues surrounding the use of information, and access and use information ethically and legally, either as an individual or a member of a group.

- Understand that information literacy is an on-going process and uses a variety of 
methods and emerging technologies for keeping abreast of trends in the field.

These standards are captured in Kuhlthau's recent definition of information literacy; that is the ability to locate, evaluate and use information wisely for learning, thinking and creating (2012: 6).

This section explores lecturers' perceptions of the information literacy skills of their students; that is, their ability to seek and access the information needed (standards 1 and 2), synthesise and apply them in solving academic tasks (standards 3); and their knowledge of ethical issues concerning the use of information (standard 4). Also of interest is the respondents' awareness of the concept of information literacy.

Nine respondents expressed the extent to which their students are able to seek needed information while two respondents (L7, L11) could not ascertain. Being an unusual response to a salient question, the researcher probed the respondents during a casual face to face chat. Hence, it was discovered that L7 is a fresh graduate, newly employed; he assists the senior lecturers in teaching and occasionally handles tutorial. L11 is newly employed too, and has only taught students for two months. The researchers were not aware of these details before administering the interviews, but they are of the opinion that having up to eight class sessions with students is enough to give some form of appraisal in this regard.

Of the nine respondents, four (L2, L3, L6, L12) rate their students as excellent/advanced. This means that their students have knowledge of the literature of the field, for example primary and secondary sources, and are able to construct and implement effectively designed search strategies; retrieve information using a variety of methods and tools; and as well extract, record, transfer, and manage the information. These are the performance indicators of standards one and two of the ACRL information literacy standards.

Put differently, the students are good at "finding trails and pathways" (Kuhlthau 2012: 34). Students of two of the respondents (L2, L6) were involved in the assignment and journaling which will be discussed in the subsequent sessions; therefore, their perception will be validated in the students' assignment and journals.

Two respondents (L 9, L10) rated their students as fair.

I will put that at $60 \%$ at most. Resources for information within the university are limited for now. Some students go to Petroleum Training Institute (PT1), some use the Internet and any books and eBooks they can find. 
Physical access which is the first level of access to information infrastructure is a precondition to intellectual access (Burnett ,Jaeger\& Thompson, 2008:57; Burnett \& Jaeger 2011); and it is not entirely within the control of the individuals. However, some studies have shown that students are beginning to break the barrier to physical access. An example is a large survey in the USA in which students of various nationalities are beginning to break the barrier to physical access due to ownership of portable devices such as laptops and phones on which they can gain physical access to the Internet (Dahlstrom, 2012). This is similar to the findings of Krubu (2015) in which at least two out of three students own smart phones besides the few who own java phones that are Internet enabled. Also, about one out of two own a laptop.

Regarding their ability to synthesise and use the information gathered in solving their academic tasks, five respondents (L2, L3, L5, L11, L12) rated their students as excellent/advance/impressive. This implies that their students evaluate information and its sources before selection; are able to summarise the main ideas they gather from information sources; compare their previous knowledge with the new knowledge and confirm the interpretation of the information through discourse with other individuals, small groups or teams, subject-area experts, and/or practitioners based as explicated in the performance indicator of standard four. This is explicated by Kuhlthau (2012:34) as judging usefulness by quality, expertise, accuracy, currency and perspective, determining importance, relevance, pertinence, forming a focus, deciding what is enough, summarizing, interpreting and creating, among others.

Two respondents (L8, L9) rated their students as fair while one respondent (L7), again "cannot say".

L6 explained that "the information gathered by students through assignment serve as eye opener to their academic development." This is quite pertinent in a situation where students go through a process step-by-step process in their assignment as recommended by Kuhlthau (2010:22; and 2012:16) in the concept of guided enquiry which involves a constructivist approach to learning in today's ubiquitous information environment. However, when students are not guided they may merely relate with information at a surface level.

Furthermore, one respondent (L1) expressed:

I would say 50\% at most. They are new to this kind of assignment-research and report writing. However, they did very well. Some students simply summarised without understanding the subject matter. Others put all the information obtained together and came up with their on understanding of the subject matter.

Being new to research and report writing in year three is an issue. According to FitzGerald 
(2011: 40) information literacy skills of students is addressed in a systematic way. In the case of Nigerian universities, information literacy should be addressed from 100 level and reinforced across all courses and levels. But despite this hitch, some students are able to cope well according to the lecturer. This elucidates the concept of information literacy in terms of 'seeking meaning' and 'sense-making' as an individual's cognitive abilities (Kuhlthau 2004, 2008:68).

The information literate student has knowledge of ethical issues concerning the use of information either as an individual or member of a group and uses information effectively and ethically to accomplish a task, for example, citing and acknowledging sources correctly to avoid plagiarism (Standard 4). Six respondents (L3, L4, L8, L9, L11, L12) indicated that their students are able to cite and acknowledge sources correctly while the others expressed their perceptions as follows:

L1: Yes, I specifically instructed them to do that. They had references for their reports. The references were not excellent but they made a good attempt.

L2: Yes, they cite sources but not always correctly in terms of citing format.

L5: Yes but they need more enlightenment on how to reference materials.

L6: Some do while others don't - well it is the rationale behind the teaching of the use of library as a general course in all higher institutions.

The concept of citing and acknowledging sources correctly needs to be constantly reinforced in the process of teaching and learning across all levels within the university. It can only be learned through constant practice.

Of all respondents, two (L7, L2) are not aware of the concept of information literacy.

L1 expressed that:

I just learnt about information literacy, however, I follow this concept in my approach to problems. He also added that some of my students seem to be information literate, but many of them are not, based on what I saw in their reports (assignment).

Eight respondents are of the view that their students are information literate while one (L8) mentioned that some of them are information literate.

On a general note, respondents seem to perceive their students as doing well and information literate. Nonetheless, the analysis of the students' assignment will corroborate the perception of 
lecturers' about on students' information literacy level.

\section{Qualitative analysis of students' assignment}

Third year students of electrical and electronics engineering department were administered the following assignment in Physical Electronics (EEE 314) course:

1a. What are the differences and similarities between SCR and Diode?

$b$. What are the differences and similarities between SCR and TRIAC?

c. What are the differences and similarities between SCR and DIAC?

2a. Give a brief history of the First Integrated Circuit (IC)

b. Give a brief history of Vacuum Tube

c. Give a brief history of Transistor

The handwritten assignment was administered to students in real class time with the instruction to answer the questions and add their list of references. The lecturer also encouraged the students to go online and gather some information. The assignment was dictated to the students in class; no written instruction was given. Using the ACRL Standards, the assignments was analysed in as follows:

ACRL Standard 2: The information literate student accesses needed information effectively and efficiently.

Of 50 students who participated in the assignment, 28 consulted only non-authoritative sources such as www.answers.com and Wikipedia. Another eight students used print and e-books in addition to the use of non-authoritative sources such as www.answers.com, ehow.com, and Wikipedia. This implies that they need to improve their choice and use of information sources, though this apparent inadequacy may be due to poor curriculum and teaching or disregard for sources used.

Only three students out of 50 consulted a few scholarly sources such as scientific/technical reports, journal articles and other peer-reviewed research works. This implies that the majority of the students are not quite conversant with the different information resources and formats, their purpose and audience (e.g., popular, scholarly) or they simply decided to take the easy and convenient route in their information seeking (Head\& Eisenberg, 2010; and Connaway, Dickey \& Radford, 2011).

ACRL Standard 3: The information literate student evaluates information and its sources 
critically and incorporates selected information into his or her knowledge base and value system. Students are expected to select and synthesize information to construct new meaning.

Students are expected to select and synthesise information, to construct new meaning, that is, "find trails and pathways" (Kuhlthau, 2012: 34). However, perhaps, due to the shallow nature of the assignment questions which only encouraged students to read, understand, explain and summarise (lower order thinking), rather than go beyond that to higher order thinking which encourages knowledge application, analysis, evaluating and creating (Churches, 2009), students merely listed/itemised the similarities and differences between the items without engaging in any deep intellectual foray into the subject or discourse. Also, all the students had similar brief texts to question two, concerning writing brief histories on some terms. There was actually no discussion of any sort in the assignments, a deficiency that can be directly linked to the nature of the question, in that it is incapable of satisfying such requirements as evaluate, critically examine and synthesize.

Standard 4: The information literate student, individually or as a member of a group, uses information effectively to accomplish a specific purpose.

The criterion for evaluation is the organisation of content in a manner that supports the format of assignment is one of the aspects of ACRL standard 4. According to the University of Technology Sydney Library (2013), there are different types of assignment and formats. An essay should have an introduction, body, conclusion and a reference list. A research report analyses or describes a problem. Researches, scientific and business are three types of reports. In this case, the report should be either research or scientific with the following format: abstract, introduction, body (methods, findings. discussion), conclusion and recommendation, references and appendices (if any).

In the assignment, there was no format prescribed by the lecturer, neither did the students follow any format. Again, this shortcoming is a problem with the curriculum administration and possibly the lecturer.

ACRL Standard 5: The information literate student understands many of the economic, legal, and social issues surrounding the use of information and accesses and uses information ethically and legally.

The criteria for evaluation are the acknowledgement of the use of information sources, and proper referencing and citations. 
Of the 50 assignments, 36 had a list of references while 14 had none. One cannot rule out plagiarism in this case which is not acceptable as implied in the rubric used. Thirty five (35) had several referencing errors, while only one had few referencing errors. It is pertinent to note that none of the 50 assignments had in-text citations, which indicated plagiarism.

From the foregoing analysis of 50 assignments of the 300 level students in Electrical Electronics Engineering Department, it appears the students' information literacy level is quite low, even in third year. This aligns with the views of Kerins, Madden, and Fulton (2004); King (2007); Gross and Latham (2008); MohdSaad (2008); Baro and Fyneman (2009); Abubakar and Isyaku (2012); Adetimirin (2012); Kunakornsakul and Pinit (2012) Ukpebor and Emojorho (2012); Williams (2010) ; and Krubu (2015). However, this outcome is contrary to the submission of the lecturer who taught the course and gave the assignment as the lecturer rated the students' level of information literacy as excellent/advanced.

It is expected that their information literacy level would have improved over the years (King, 2007). However, this is not the case. The current situation may be connected with poor teaching and instructions which occasioned the level of assignment question, with no clear instructions and format given.

\section{Implications of the research for theory, practice and policy}

This study has implications for theory especially in the context of tertiary education. The contributions of this current study to practice and policy are addressed in various ways as follows:

\section{Implications of the research for theory}

For quality assurance in teaching and learning, Quality Education in Developing Countries (QEDC)(2008) strategies and QEDC theory of change under the Hewlett Foundation's Global Development Program (HFGDP) affirm that

if more attention to and accountability for student learning exist in a country (1), if governments and educators have knowledge about effective instructional models that can be scaled (2), and if the necessary resources are in place to ensure student learning (3), policy and practice within the system (from donor practice to teacher behaviour) will change to produce improved student learning (QEDC, 2008:11).

This theory will serve as invaluable at the point of evaluation and genuine intervention in teaching and learning. 


\section{Implications of the research for practice}

Students' information handling skills is poor but the fact that some lecturers, teacher librarians and especially the course lecturer who administered the assignment rated the students in this study as very good and excellent (in information literacy) is an indication that the assumption that lecturers/librarians are information literate and are therefore capable of teaching learners information literacy may be wrong. Consequently, there is an urgent need for the university to put in place regular information literacy education in-service programmes for the teaching staff; this will go a long way to enhance their knowledge base and teaching capacity.

\section{Implications of the research for policy}

- The Nigerian Library Association (NLA) should work in collaboration with the Department of Academic Standards (DASs) of National Universities Commission (NUC) to develop an information literacy education policy by setting a benchmark and ensuring the implementation of information literacy education for Nigerian universities. A curriculum of information literacy education that goes beyond teaching library skills should be in use. The curriculum should bring to bear all the elements and units of information literacy education that would prepare the Nigerian undergraduates for the Vision 20:2020 work place.

\section{Conclusion}

The research work focused on lecturers' perception of students' information literacy skills vs. students' actual information literacy levels.

Eleven lecturers in the various departments in both Colleges of Science and Technology including two teacher-librarians were administered 12 open-ended interview protocols to investigate students' information literacy levels, particularly, how they seek and use information. On the other hand, individual assignments of the entire 50, third year students in the department Electrical Electronics Engineering Departments were examined with a view to their level of students' information handling skills. The assignment scripts were analysed using a rubric founded on the ACRL information literacy standards (ACRL, 2012), prepared by the researchers.

Findings reveal that students' information literacy level is quite low, even in third year while the lecturers presents an elevated impression of students' information literacy levels, rating them as excellent/advanced. 
In conclusion, the study recommends the Quality Education in Developing Countries (QEDC)(2008) strategies and QEDC theory of change to serve as point of evaluation and genuine intervention in teaching and learning. The study also recommends regular information literacy education in-service programmes for the teaching staff to aid in enhancing their teaching capacity. The Nigerian Library Association (NLA) should work to develop an information literacy education policy for Nigerian universities.

\section{References}

Abubakar, U. A. \&Isyaku, A. A. (2012). Teaching Information Literacy Skills in Nigerian Universities: Whose Responsibility? Journal of Research in Education and Society, 3(2): 33-42.

Adetimirin, A.E. (2012). ICT literacy among undergraduates in Nigerian universities.EducInfTechnol, (2012)17: 381-397.

Adeyemi, A.A. (2010) Correlate of information literacy skills among Undergraduate Students in Nigeria. Nigerian Journal of Educational Technology, Vol.23, No. 2, pp34-41

American Library Association (2000). The information literacy competency standards for higher education.Online

\{ Available

$<\underline{\text { http://www.ala.org/acrl/standards/informationliteracycompetency }}>$ [Accessed January $10,2013]$

Armstrong C. (2005) defining information literacy for UTC library and information update. Journal/February 4 (1) 22-25.

Association of College and Research Libraries (ACRL) (2005).Information Literacy Standards for Higher Education.Online $\{$ Available $\}<$ http://www.ala.org/acrl/sites/ala.org.acrl/files/content/standards/standards.p

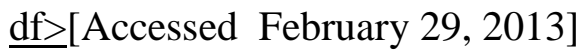

Association of College and Research Libraries/American Library Association (2012).Information Literacy Standards for Science and Engineering/Technology.The ALA/ACRL/STS Task Force on Information Literacy for Science and Technology. Online

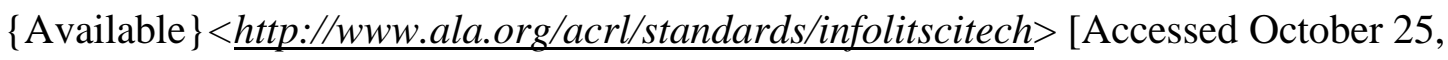

Association of College and Research Libraries/American Library Association (2012).Information Literacy Standards for Science and Engineering/Technology.The ALA/ACRL/STS Task Force on Information Literacy for Science and 
Lecturers' perception of students' information literacy skills versus students' actual information literacy levels

Technology.Online $\{$ Available $\}<$ http://www.ala.org/acrl/standards/infolitscitech $>$ [Accessed October 25, 2012]

Baro, E.E. \&Fyneman, B.(2009). Information literacy among undergraduate students in Niger Delta University.The Electronic Library, 27 (4): 659-675.

Bellardo, T. (1985). What do we really know about online searchers? Online review, (9(3), 223239.

Online

\{Available

<http://www.emeraldinsight.com/journals.htm?articleid=1653089 $>$ [Accessed April 13, 2012]

Burnett, G. \& Jaeger, P.T. (2011). The theory of information worlds and information behaviour. In New Directions in Information Behaviour (Library and Information Science, Volume 1). Edited bySpink, A. \&Heinström, J. (pp. 161-180). Emerald Group Publishing Limited. Online

\{Available <http://www.emeraldinsight.com/books.htm?chapterid=1953619>[Accessed April 16, 2012]

Burnett, G., Jaeger, P.T., \& Thompson, K.M. (2008). Normative behaviour and information: the social aspects of information access. Library \& Information Science Research, 30(1):56-66.

Centre for Information Behaviour and the Evaluation of Research (CIBER) (2008). Information behaviour of the researcher of the future. (pp.1-35). Online \{Available\} <http://www.jisc.ac.uk/media/documents/programmes/reppres/gg_final_keynote_110120 08.pdfhttp://net.educause.edu/ir/library/pdf/CSD4781.pdf> [Accessed February 28, 2013]

Churches, A. (2009).Bloom's Digital Taxonomy.Educational Origami.

Connaway, L.S., Dickey, T.J., and Radford, M.L. (2011). 'If it is too inconvenient, i'm not going after it.:' convenience as a critical factor in information-seeking Behaviors.Library and Information Science Research. 179-190. $\langle$ http://www.oclc.org/research/publications/library/2011/connaway-lisr.pdf> [Accessed January 10, 2013].

Dahlstrom, E. (2012). ECAR study of undergraduate students and information technology.(Research Report). Louisville, CO: EDUCAUSE Centre for Applied Research (September, Online 2012). A Available\} <http://net.educause.edu/ir/library/pdf/ERS1208/ERS1208.pdf> [Accessed October, 16 
2012]

Dubicki, E. 2013.Faculty perceptions of students' information literacy skills competencies. Journal of Information Literacy, 7(2): 97-125. http://dx.doi.org/10.11645/7.2.1852

FitzGerald, L. (2011). The twin purposes of Guided Inquiry: guiding student inquiry and evidence based practice. Scan 30(1), 26-41 Online \{Available\} $<$ http://www.curriculumsupport.education.nsw.gov.au/schoollibraries/assets/pdf/guidede nquiry.pdf $>$ [Accessed September 17, 2012]

Fontana, A. \& Frey, J.H. (2008). The interview: from neutral stance to political involvement. In Collecting and interpreting qualitative materials.Edited by Denzin, N.\& Lincoln, Y. (pp. 115-159) Thousand Oaks, CA: Sage Publications.

Johnson, B. \& Webber S. (2003). Information Literacy in Higher Education: a review and case study. Studies in Higher Education 28 (3): 335-352

Gross, M. \& Latham, D. (2008). Self -views of information-seeking skills: undergraduates' understanding of what it means to be information literate. 2007 OCLC/ALISE OCLC Research. Online $\quad$ Available\} $\langle$ http://library.oclc.org/cdm/singleitem/collection/p267701coll27/id/273/rec/15 > [Accessed April 20, 2012]

Head, A. J., \& Eisenberg, M. B. (2010). How today's college students use Wikipedia for courserelated research. First Monday, 15(3). Online \{Available\} $<$ http://www.uic.edu/htbin/cgiwrap/bin/ojs/index.php/fm/article/viewArticle/2830/24>[A ccessed October 20, 2013]

Kerins, G. Madden, R. \& Fulton, C. (2004). Information seeking and students studying for professional careers: the cases of engineering and law students in Ireland. Information Research, 10(1), paper 208. Online \{Available\} <http://informationr.net/ir/101/paper208.html $>$ [Accessed June 2, 2013]

King, L. (2007). Information literacy of incoming undergraduate Arts students at the University of the Western Cape: assessment of competencies and proficiencies. PhD Thesis. Bellville: University of the Western Cape.

Krubu, D.E. (2013). Some reflections on the Theory of Information Worlds as a Theoretical Framework for Information Behaviour Research. MOUSAION, 31(3): 1-14. University of South Africa Press. 2013. 
Krubu, D.E (2015). Information Behaviour of Nigerian Undergraduates in the World of Web 2.0: The Case of Federal University of Petroleum Resources, Delta State, Nigeria, a Specialized University. PhD Thesis. Bellville: University of the Western Cape.

Kuhlthau, C. C. (2004). Seeking meaning: A process approach to library and information services. $2^{\text {nd }}$ edition. Westport, CT: Libraries Unlimited.

Kuhlthau, C.C. (2008). From Information to Meaning: Confronting Challenges of the Twentyfirst Century. Libri, 58: 66-73. Online \{Available\} <http://ocacinformationliteracy.pbworks.com/w/file/fetch/30835148/Kuhlthau.FromInfo rmationToMeaning.pdf $>$ [Accessed October 3, 2012]

Kuhlthau, C.C. (2010). Guided Inquiry: School Libraries in the 21st Century.SchoolLibraries Worldwide, 16(1): 17-28. Online Available\} <http://comminfo.rutgers.edu/ kuhlthau/docs/GI-School-Librarians-in-the-21Century.pdf $>$ [Accessed May 27, 2013]

Kuhlthau, C.C (2012). Librarians facilitating learning through guided inquiry. https://iflasatellitetampere2012.files.wordpress.com/2012/08/auditorium_keynote_kuhlth au.pdf

Kunakornsakul, H.\&Pinit, P. (2012). 21st Century Skills of Undergraduate Students in Science and Technology: An Information Literacy Assessment. The Proceedings of International e-Learning Conference 2012(IEC2012).June 14-15, Muang Thong Thani, Thailand.Online \{Available\} <http://support.thaicyberu.go.th/iec2012/proc.pdf $>>$ [Accessed October 2, 2012]

McGuinness, C. 2006. What faculty think - exploring the barriers to information literacy development in undergraduate education. The Journal of Academic Librarianship 32(6): 573-582. Available at: http://dx.doi.org/10.1016/j.acalib.2006.06.002.

MohdSaad, M.S. (2008). Ascertaining Information Literacy and Information Seeking Behaviour of Students Conducting Final Year Project.PhD Dissertation, University of Malaysia. Online \{Available\} <http://dspace.fsktm.um.edu.my/handle/1812/137> [Accessed April 27, 2012].

Ojedokun A.A.(2007). Information literacy for tertiary education students in African. Ibadan: Third World Information Service.

Quality Education in Developing Countries Initiative (QECD) (2008). The Quality Education in Developing Countries Initiative Grantmaking Strategy (QEDC). Online \{Available\} 
Lecturers' perception of students' information literacy skills versus students' actual information literacy levels

http://www.hewlett.org/uploads/files/QEDCGrantmakingStrategy_Final.pdf [Accessed April 22, 2015]

Rockman, I. (2004). Introduction: the importance of information literacy. In the I.R, Association (Ed), Integrating information literacy into the higher education curriculum: practical models for transformation (pp. 1-28). San Francisco. Jossey-Bass.

Ukpebor, C.O. \&Emojorho, D. (2012). Information Literacy Skills: A Survey of the Transition of Students from Secondary to University Education in Edo State, Nigeria. Library Philosophy and Practice, Paper 824:1-8. Online \{Available\} $\langle$ http://digitalcommons.unl.edu/cgi/viewcontent.cgi?article=2073\&context=libphilprac $>$ [Accessed March 7, 2013]

University of Technology Sydney Library (2013). Assignment types. Online \{Available\} $<$ https://www.lib.uts.edu.au/sites/default/files/attachments/page/Academic\%20Writing\% 20Guide\%20Part\%202\%20-\%20Assignment\%20Types.pdf> [Accessed December 11, 2014]

Williams C. (2010). Changing user behaviour on the Web - what does this mean for the development of online information literacy tools? Paper presented at LILAC 2010, Limerick, Republic of Ireland, 29-31 March 2010.

Kuhlthau, C.C (2012). Librarians facilitating learning through guided inquiry. https://iflasatellitetampere2012.files.wordpress.com/2012/08/auditorium_keynote_kuhlth au.pdf

\author{
Dorcas Ejemeh Krubu, PhD; OgagaOghene Uzezi Idhalama \& Chirstopher Omigie are \\ lecturers in the Department of Library and Information Science \\ Faculty of Social Science, Ambrose Alli University, PMB 14 \\ Edo State, Nigeria \\ dorcas.krubu@aauekpoma.edu.ng
}

